\title{
HUBUNGAN ANTARA KONFORMITAS KELOMPOK TEMAN SEBAYA DENGAN DISIPLIN SISWA SMA NEGERI 5 PADANG
}

Irfan Setiawan, Ike Sylvia

Alumni Jurusan Sosiologi, FIS Universitas Negeri Padang

Abstrak

Penelitian ini bertujuan untuk mengetahui hubungan antara kelompok teman sebaya dengan disiplin siswa di SMA Negeri 5 Padang. Jenis penelitian ini tergolong penelitian ex post facto. Subjek dalam penelitian ini adalah siswa SMA Negeri 5 Padang yang terdaftar pada tahun pelajaran 2011/2012. Sampel penelitian ini diambil secara stratified random sampling dengan jumlah sampel sebanyak 91 orang. Penelitian ini menggunakan dua macam variabel yaitu: 1) variabel bebas: konformitas kelompok teman sebaya (X), 2) variabel terikat: disiplin siswa (Y). Pengumpulan data untuk variabel konformitas kelompok teman sebaya dan disiplin siswa menggunakan metode angket dengan skala Likert. Keabsahan data diperoleh melalui uji validitas dan reliabilitas. Teknik analisis data yang digunakan adalah analisis deskriptif untuk menghitung harga mean, median, modus, dan standar deviasi. Teknik analisis data yang digunakan antara lain kategorisasi berjenjang (ordinal), uji normalitas dengan rumus Liliefors, Analisis data untuk uji hipotesis menggunakan rumus korelasi product moment dan untuk mengetahui besarnya persentase derajat pengaruh variabel $\mathrm{X}$ terhadap variabel $\mathrm{Y}$ digunakan koefisien determinasi. Hasil uji hipotesis dengan rumus korelasi product-moment diperoleh nilai rhitung 0.570 sedangkan nilai rtabel 0.207 , hal ini berarti terdapat hubungan antara konformitas kelompok teman sebaya dengan disiplin siswa. Sumbangan konformitas kelompok teman sebaya terhadap disiplin siswa adalah

Kata Kunci

Konformitas, teman sebaya $32,49 \%$ dan sisanya $67,51 \%$ dipengaruhi faktor lain seperti faktor psikologis, lingkungan dan perseorangan.

(C) 2012 Universitas Negeri Padang 


\section{Pendahuluan}

Sekolah sebagai lembaga pendidikan mempunyai kebijakan tertentu yang dituangkan dalam bentuk aturan sekolah yang disebut dengan tata tertib. Siswa dituntut untuk menaati tata tertib sekolah, dengan demikian akan membentuk karakteristik siswa agar disiplin dan bertanggung jawab. Tata tertib sekolah dapat berjalan dengan baik apabila sikap disiplin terhadap tata tertib atau peraturan sekolah, berjalan dengan baik. Menurut Soegeng Prijodarminto (1992: 23) "disiplin suatu kondisi yang tercipta dan terbentuk melalui proses dari serangkaian perilaku yang menunjukkan nilai-nilai ketaatan, kesetiaan, keteraturan dan atau ketertiban".

Peraturan sekolah dibuat agar siswa dapat beradaptasi dengan lingkungan sekolah, mengontrol diri dan bertanggung jawab serta berperilaku sesuai dengan tuntutan lingkungan sekolah. Disiplin sekolah dianggap sebagai sarana agar proses belajar dapat efektif, karena tujuan disiplin di sekolah adalah efektifitas proses belajar mengajar, maka perilaku yang dianggap mendukung proses belajar mengajar dianggap masalah disiplin (Syahril dkk,2009: 154).

Siswa sekolah menengah atas merupakan remaja yang berada pada masa peralihan dari anak-anak menuju proses kedewasaan yang ditandai dengan emosi yang masih belum stabil dan masih berusaha untuk menunjukkan identitas diri. Masa-masa ini hubungan remaja dengan teman sebaya lebih akrab, mereka bahkan lebih banyak menghabiskan waktunya di luar rumah bersama teman sebayanya dibandingkan bersama keluarga.

Kuatnya pengaruh kelompok teman sebaya terjadi karena remaja lebih banyak berada di luar rumah bersama teman sebaya sebagai kelompok. Kelompok teman sebaya memiliki aturan tertentu yang harus dipatuhi oleh remaja sebagai anggota kelompoknya. Penyesuaian remaja terhadap norma dengan perilaku sama dengan kelompok teman sebaya disebut konformitas (Monks dkk, 2004:382).

Dasar utama dari konformitas adalah ketika individu melakukan aktivitas dimana terdapat tendensi yang kuat untuk melakukan sesuatu yang sama dengan yang lainnya, walaupun tindakan tersebut merupakan cara-cara yang menyimpang. Remaja yang mempunyai tingkat konformitas tinggi akan lebih banyak tergantung pada aturan dan norma yang berlaku dalam kelompoknya, sehingga remaja cenderung mendistribusikan setiap aktivitasnya sebagai usaha kelompok, bukan usahanya sendiri (Monks dkk, 2004: 283). Dalam kondisi seperti ini, dapat dikatakan bahwa motivasi untuk menuruti ajakan dan aturan kelompok cukup tinggi pada remaja, karena menganggap aturan kelompok adalah yang paling benar serta ditandai dengan berbagai usaha yang dilakukan remaja agar diterima dan diakui keberadaannya dalam kelompok. Kondisi emosional yang labil pada remaja juga turut mendorong individu untuk lebih mudah melakukan konformitas.

Hasil observasi awal yang penulis lakukan di SMA Negeri 5 Padang, ditemukan beberapa pelanggaran disiplin yang dilakukan siswa seperti: terlambat mengikuti upacara, tidak melengkapi atribut upacara. Di luar sekolah penulis melihat banyak siswa yang tidak mengikuti upacara bendera dan malahan mereka bekeliaran di sekitar sekolah. Hasil wawancara dengan salah seorang guru BK di SMA N 5 Padang yang bernama Ernofia, S.Pd (54 tahun) peneliti memperoleh data bahwa terdapat pelanggaran terhadap disiplin, hal ini meliputi jenis pelanggaran terlambat masuk sekolah, bolos saat jam pelajaran, berpakaian tidak rapi.

Data yang peneliti dapatkan dari pihak sekolah terdapat pelanggaran disiplin yang totalnya berjumlah 396 dengan rincian $34 \%$ pelanggaran disiplin bolos, $46 \%$ pelanggaran disiplin waktu yakni terlambat dan $20 \%$ nya pelanggaran atribut sekolah. Dari hasil ini menjelaskan bah- 
wasanya terdapat permasalahan pada disiplin siswa SMA Negeri 5 Padang.

Menurut Crow and Crow (1990: 114) faktor-faktor yang mempengaruhi disiplin siswa diantaranya adalah faktor psikologi, faktor perseorangan, faktor sosial dan faktor lingkungan. Dari faktor yang mempengaruhi disiplin, faktor yang paling berpengaruh adalah faktor sosial dimana dalam faktor sosial tersebut terdapat hubungan teman sebaya, hal ini dikarenakan siswa lebih banyak menghabiskan banyak waktunya bersama teman sebayanya. Berkaitan dengan hubungan sosial, siswa juga harus menyesuaikan diri dengan orang di luar lingkungan keluarganya.

Hurlock (1994: 213) menjelaskan kebutuhan untuk diterima dalam kelompok teman sebaya menyebabkan remaja melakukan perubahan dalam sikap dan perilaku sesuai dengan perilaku anggota kelompok teman sebaya. Demikian pula bila anggota kelompok mencoba bolos, cabut, ribut, tidak buat PR, atau merokok, maka remaja cenderung mengikutinya tanpa memperdulikan akibatnya bagi diri mereka sendiri. Hal tersebut tidak mengherankan, alasannya terkadang remaja yang dalam hal ini siswa begitu ingin diterima sehingga akan melakukan apapun sesuai penilaian dan persetujuan dari kelompok teman sebaya agar diterima dan diakui keberadaannya dalam kelompok, termasuk berprilaku indisipliner. Dalam pergaulan remaja, kebutuhan untuk dapat diterima bagi setiap individu merupakan suatu hal yang sangat mutlak sebagai makhluk sosial.

Dari uraian permasalahan di atas, maka penulis tertarik untuk meneliti tentang "Hubungan antara Konformitas Kelompok Teman Sebaya dengan Disiplin Siswa SMA Negeri 5 Padang.

\section{Metode Penelitian}

Jenis penelitian ini adalah penelitian kuantitatif dengan desain ex-post facto. Berdasarkan hubungan antaravariabel yang diteliti, penelitian ini dapat dikelompokkan sebagai penelitian koleratif yakni bertujuan untuk mengetahui ada atau tidaknya hubungan antara dua variabel atau lebih.

Populasi penelitian ini adalah semua siswa SMA Negeri 5 Padang tahun ajaran 2011/2012. Pengambilan sampel menggunakan teknik stratified Random Sampling. Cara menghitung ukuran sampel melalui cara Solvin dengan taraf kesalahan $10 \%$. Pada tahap akhir kuesioner disebar kepada 91 responden yakni siswa kelas X 34 orang, kelas XI 31 orang dan kelas XII 26 orang. Penelitian ini menggunakan dua macam variabel yaitu: 1) variabel bebas: konformitas kelompok teman sebaya $(X), 2$ ) variabel terikat: disiplin siswa $(\mathrm{Y})$. Pengumpulan data untuk variabel konformitas kelompok teman sebaya dan disiplin siswa menggunakan metode angket dengan skala Likert. Skala konformitas kelompok teman sebaya dan disiplin siswa disajikan dalam pernyataan favorable dan unfavorable dengan empat alteratif jawaban, yaitu SL (Selalu), SR (Seringi), JR (Jarang), TP (Tidak Pernah)

Hasil uji validitas kuesioner menunjukkan bahwa dari 29 butir pernyataan konformitas kelompok teman sebaya 25 butir dinyatakan valid, untuk disiplin siswa dari 23 butir pernyataan dinyatakan 20 butir valid. Hasil perhitungan reliabilitas menunjukkan koefisien reliabilitas untuk variabel konformitas kelompok teman sebaya o,655 dengan interpretasi pada kategori tinggi dan disiplin siswa sebesar o,863 sehingga dapat disimpulkan bahwa instrumen yang digunakan reliabel dengan interpretasi pada kategoti sangat kuat.

Teknik analisis data dalam penelitian ini menggunakan analisis korelasi Product Moment, terlebih dahulu dilakukan uji persyaratan penelitian yaitu uji normalitas. Pengujian normalitas data dimaksudkan untuk menguji asumsi bahwa data berdistribusi normal. Uji normalitas dilakukan dengan menggunakan uji Lilliefors. Sebaran data berdistribusi normal jika skor Sig. Lilliefors yang di- 
Irfan Setiawan, Ike Sylvia, HUBUNGAN ANTARA KONFORMITAS ...

peroleh lebih besar alpha o,05 dengan $\mathrm{N}$ 91 dan Ltabel $=0,0928$.

\section{Hasil Penelitian dan Pembahasan}

Hasil uji normalitas menunjukkan bahwa kedua variabel dalam penelitian ini memiliki distribusi normal. Hal tersebut dapat dilihat dari uji normalitas sebagai berikut:

\begin{tabular}{|c|c|c|c|c|}
\hline Variabel & $\mathbf{N}$ & LO & Ltabel & Keterangan \\
\hline $\begin{array}{l}\text { Konformitas Teman } \\
\text { Sebaya } \\
\text { (X) }\end{array}$ & 91 & 0.0906 & 0.0928 & Normal \\
\hline $\begin{array}{l}\text { Disiplin } \\
\text { (Y) }\end{array}$ & 91 & 0.0917 & 0.0928 & Normal \\
\hline
\end{tabular}

Dari tabel di atas dapat dilihat bahwa skor signifikansi Lilliefors untuk variabel $\mathrm{X}$ sebesar o,0906 dan variabel $\mathrm{Y}$ sebesar 0,0917. Dengan demikian dapat dinyatakan bahwa data dari kedua variabel dalam penelitian ini sebarannya membentuk distribusi normal. Karena kedua Lo dari kedua variabel tersebut lebih kecil dari Ltabel Artinya sebaran data umumnya lebih banyak pada posisi rata-rata.

Berdasarkan uji hipotesis yang dilakukan dengan menggunakan rumus korelasi Product-Moment, ternyata konformitas kelompok teman sebaya memiliki hubungan dengan disiplin siswa SMA Negeri 5 Padang dengan perbandingan harga $\mathrm{r}$ yaitu $\mathrm{r}_{\text {hitung }}>\mathrm{r}_{\text {tabel }}$ dimana $\mathrm{r}_{\text {hitung }} 0.570$ sedangkan nilai $\mathrm{r}_{\text {tabel }}$ o.207. Dengan demikian hipotesis $\mathrm{H}_{\mathrm{o}}$ ditolak sedangkan $\mathrm{H}_{1}$ yang menyatakan terdapat hubungan antara konformitaas teman sebaya dengan disiplin diterima.

Koefesien determinasi $\mathrm{r}^{2}$ Square sebesar o,3249 hal ini menunjukkan sumbangan konformitas kelompok teman sebaya terhadap disiplin siswa adalah sebesar $32,49 \%$ sedangkan untuk sisanya $67,51 \%$ disumbangkan oleh faktor-faktor lain.

\section{Konformitas Kelompok Teman Sebaya}

Konformitas merupakan suatu tuntutan yang tidak tertulis dalam kelompok teman sebaya terhadap anggotanya, namun memiliki pengaruh yang kuat dan dapat menimbulakan perilaku tertentu pada anggota kelompok tersebut. Seorang anak seringkali melakukan konformitas agar diterima dalam kelompok dan menjaga harmonisasi sosial kelompok tersebut. Konformitas memiliki tiga indikator antara lain kekompakan, kesepakatan, dan ketaatan.

Variabel konformitas kelompok teman sebaya diukur dengan sistem kategorisasi yang bertujuan untuk menempatkan siswa kedalam kelompok-kelompok terpisah secara berjenjang. Berikut pengkategorisasian tiga level yang digunakan dalam penelitian ini (Saifuddin,1999: 109).

Rumus Kategorisasi Jenjang (Ordinal)

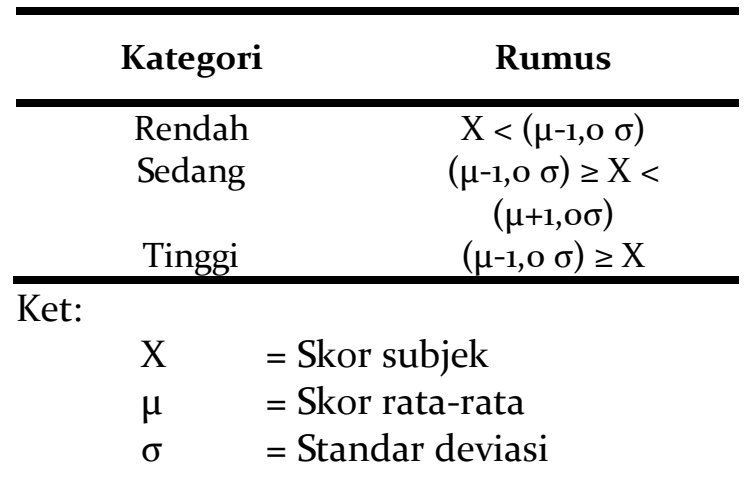


Irfan Setiawan, Ike Sylvia, HUBUNGAN ANTARA KONFORMITAS ...

Berdasarkan pada hasil penelitian, dari 91 siswa SMAN 5 Padang sebanyak $23,07 \%$ atau 21 siswa memiliki konformitas kelompok teman sebaya rendah. Selanjutnya $48,35 \%$ atau 44 siswa memiliki konformitas kelompok teman sebaya sedang dan $28.57 \%$ atau 26 siswa memiliki konformitas kelompok teman sebaya tinggi. Hal ini berarti mayoritas siswa SMA Negeri 5 Padang memiliki konformitas teman sebaya pada kategori sedang. Berikut ulasan profil umum konformitas kelompok teman sebaya per sub indikator.

\begin{tabular}{|c|c|c|c|c|}
\hline No & Indikator & Sub Indikator & Kategori & Persentase (\%) \\
\hline \multirow[t]{6}{*}{1} & \multirow[t]{6}{*}{ Kekompakan } & \multirow{3}{*}{$\begin{array}{l}\text { Perasaan dekat dengan } \\
\text { anggota kelompok }\end{array}$} & Rendah & 5.49 \\
\hline & & & Sedang & 73.62 \\
\hline & & & Tinggi & 20.87 \\
\hline & & \multirow{3}{*}{$\begin{array}{l}\text { Perhatian terhadap anggota } \\
\text { kelompok }\end{array}$} & Rendah & 8.79 \\
\hline & & & Sedang & 65.93 \\
\hline & & & Tinggi & 25.27 \\
\hline \multirow[t]{9}{*}{2} & \multirow[t]{9}{*}{ Kesepakatan } & \multirow{3}{*}{$\begin{array}{l}\text { Kepercayaan terhadap anggota } \\
\text { kelompok }\end{array}$} & Rendah & 6.59 \\
\hline & & & Sedang & 71.42 \\
\hline & & & Tinggi & 21.97 \\
\hline & & \multirow{3}{*}{$\begin{array}{l}\text { Persamaan pendapat dengan } \\
\text { pendapat kelompok }\end{array}$} & Rendah & 13.18 \\
\hline & & & Sedang & 53.84 \\
\hline & & & Tinggi & 32.96 \\
\hline & & \multirow{3}{*}{$\begin{array}{l}\text { Tidak melakukan } \\
\text { penyimpangan terhadap } \\
\text { kelompok }\end{array}$} & Rendah & 12.08 \\
\hline & & & Sedang & 64.83 \\
\hline & & & Tinggi & 23.07 \\
\hline \multirow[t]{6}{*}{3} & \multirow[t]{6}{*}{ Ketaatan } & \multirow{6}{*}{$\begin{array}{l}\text { Kepatuhan melakukan } \\
\text { tindakan karena adanya } \\
\text { ganjaran dan ancaman } \\
\text { Kerelaan memenuhi harapan } \\
\text { orang lain. }\end{array}$} & Rendah & 20.87 \\
\hline & & & Sedang & $43 \cdot 95$ \\
\hline & & & Tinggi & 35.16 \\
\hline & & & Rendah & $17 \cdot 58$ \\
\hline & & & Sedang & 47.25 \\
\hline & & & Tinggi & 35.16 \\
\hline
\end{tabular}

Dari hasil statistik ini dapat dikatakan siswa SMA Negeri 5 Padang memiliki konformitas kelompok teman sebaya dalam kategori sedang. Kategori sedang artinya adalah kecendrungan seorang siswa untuk merubah prilaku sesuai dengan indikator kekompakkan, kesepakatan dan ketaatan tidak mempengaruhi secara signifikan bagi siswa dalam berprilaku. Sesuai dengan teori referensi group yang terdiri dari kelompok referensi normatif, kelompok referensi komparatif dan kelompok referensi keanggotaan. Dalam hal ini siswa SMAN 5 Padang merupakan kelompok referensi normatif yakni suatu kelompok yang menempatkan individu-individu dalam standar norma dan moral. Kelompok tidak memiliki kekuatan untuk menentukan prilaku anggotanya, individu memiliki kebebasan dalam berprilaku dan bertindak sesuai dengan pandangan individu tersendiri. Individu dalam kelompok masih memiliki pandangan terhadap norma dan nilai yang berlaku dalam masyarakat.

Dapat disimpulkan bahwa konformitas teman sebaya yang ditampilkan siswa SMAN 5 Padang tahun ajaran 2011/2012 berada pada kategori sedang artinya siswa memiliki konformitas yang tidak berlebihan terhadap kelompok teman sebayanya, karena siswa SMA Negeri 5 Padang berada dalam kelompok normatif, yang mana individu memiliki kebebasan dalam memilih dan menentukan sikap terhadap tindakan kelompok. 


\section{Disiplin Siswa}

Disiplin berguna untuk menyadarkan seseorang bahwa dirinya perlu menghargai orang lain dengan cara mentaati dan mematuhi peraturan yang berlaku, sehingga tidak akan merugikan pihak lain dan hubungan antar sesama akan menjadi baik dan lancar. Disiplin memiliki tiga indikator yakni ketepatan waktu, ke- sadaran dan ketaatan. Dari 91 siswa yang dijadikan responden sebanyak $24.17 \%$ atau 22 siswa memiliki tingkat disiplin yang rendah. Sebanyak $47,25 \%$ atau 43 siswa memiliki disiplin sedang dan $28.57 \%$ atau 26 siswa lainnya memiliki disiplin tinggi. Hal ini berarti mayoritas siswa SMAN 5 Padang memiliki tingkat disiplin yang sedang. Berikut rincian perindikator:

\begin{tabular}{|c|c|c|c|c|}
\hline No & Indikator & Sub Indikator & Kategori & $\begin{array}{c}\text { Persentase } \\
(\%)\end{array}$ \\
\hline \multirow[t]{6}{*}{1} & \multirow{6}{*}{$\begin{array}{l}\text { Ketepatan } \\
\text { waktu }\end{array}$} & \multirow{3}{*}{$\begin{array}{l}\text { Menghargai batas-batas } \\
\text { waktu }\end{array}$} & Rendah & $17 \cdot 58$ \\
\hline & & & Sedang & 57.14 \\
\hline & & & Tingggi & 25.27 \\
\hline & & \multirow[t]{3}{*}{ Patuh terhadap tata tertib } & Rendah & 14.28 \\
\hline & & & Sedang & 61.53 \\
\hline & & & Tinggi & 24.17 \\
\hline \multirow[t]{6}{*}{2} & \multirow[t]{6}{*}{ Kesadaran } & \multirow[t]{3}{*}{ Keinginan dari diri sendiri } & Rendah & 8.79 \\
\hline & & & Sedang & 54.94 \\
\hline & & & Tinggi & 36.26 \\
\hline & & \multirow[t]{3}{*}{ Pengambilan keputusan } & Rendah & $5 \cdot 49$ \\
\hline & & & Sedang & $59 \cdot 34$ \\
\hline & & & Tinggi & 35.16 \\
\hline \multirow[t]{6}{*}{3} & \multirow[t]{6}{*}{ Kepatuhan } & \multirow{3}{*}{$\begin{array}{l}\text { Kesanggupan mematuhi } \\
\text { aturan }\end{array}$} & Rendah & 1.09 \\
\hline & & & Sedang & 68.13 \\
\hline & & & Tinggi & 30.76 \\
\hline & & \multirow{3}{*}{$\begin{array}{l}\text { Kesanggupan untuk tidak } \\
\text { melanggar }\end{array}$} & Rendah & 6.59 \\
\hline & & & Sedang & 48.35 \\
\hline & & & Tinggi & 45.05 \\
\hline
\end{tabular}

Disiplin adalah suatu sikap konsisten dalam melakukan sesuatu kegiatan yang perlu dibudayakan di sekolah berkaitan dengan nilai dasar ini antara lain: tepat waktu masuk sekolah, mengikuti pertemuan atau kegiatan lain yang dijadwalkan oleh sekolah (Depdiknas, 20o1: 7). Disiplin berguna untuk menyadarkan seseorang bahwa dirinya perlu menghargai orang lain dengan cara mentaati dan mematuhi peraturan yang berlaku, sehingga tidak akan merugikan pihak lain dan hubungan antar sesama akan menjadi baik dan lancar.

Hasil penelitian pada indikator ketepatan waktu diperoleh $8,79 \%$ siswa berada pada kategori rendah, 69,23\% kategori sedang dan 20\% kategori tinggi. Dengan demikian mayoritas siswa me- miliki ketepatan waktu pada kategori sedang, hal ini dapat diinterpretasikan bahwa dalam pembentukan disiplin, siswa tidak cendrung dipengaruhi oleh faktor faktor sosialnya saja yakni kelompok teman sebaya. Kelompok teman sebaya yang merupakan tempat siswa berinteraksi dan bersosialisasi tidak memiliki pengaruh signifikan terhadap disiplin siswa. Sosialisasi dan penanam norma pada individu dalam keluarga terhadap menghargai waktu dan patuh terhadap tata tertib juga memiliki peran yang kuat dalam pengembangan disiplin siswa. Dengan demikian indikator ketepatan waktu tidak saja dipengaruhi oleh faktor sosial teman sebaya namun faktor lingkungan keluarga juga memiliki kontribusi dalam disiplin siswa. 
Irfan Setiawan, Ike Sylvia, HUBUNGAN ANTARA KONFORMITAS ...

Pada indikator kedua yakni kesadaran, diperoleh $8,79 \%$ siswa berada pada kategori rendah, $69,23 \%$ berada pada kategori sedang dan $21,97 \%$ berada pada kategori tinggi. Hal ini berarti mayoritas siswa SMA Negeri 5 Padang memiliki tingkat kesadaran yang sedang. Kategori sedang dalam indikator kesadaran ini dapat diinterpretasikan bahwa siswa memiliki kemampuan untuk mengambil keputusan atau tindakan tanpa menunggu perintah dari orang lain. Sesuai dengan pernyataan Nitisesmito (1982: 78) yang mengemukan bahwa kesadaran adalah sesuatu yang tumbuh dari dalam diri seseorang tanpa diperintah dari orang lain, seperti halnya, ide-ide maupun kreasikreasi yang memberikan manfaat terhadap pekerjaan yang dilakukan. Dapat disimpulkan sikap kesadaran disiplin tidak hanya dipengaruhi oleh kelompok teman sebaya namun faktor psikologis dan perseorangan juga memiliki kontribusi dalam pembentukan kesadaran disiplin siswa.

Pada indikator ketiga disiplin yakni kepatuhan, diperoleh 8,79\% siswa berada pada kategori rendah, $69,23 \%$ berada pada kategori sedang dan $21,97 \%$ pada kategori tinggi. Hal ini berarti mayoritas siswa memiliki kepatuhan yang sedang. Kepatuhan menurut Siswanto Sastrohadiwirya (2002: 235) adalah kesanggupan seseorang untuk mematuhi segala peraturan yang berlaku, mematuhi perintah yang diberikan pimpinan yang berwenang, serta kesanggupan untuk tidak melanggar larangan yang telah ditetapkan baik secara tertulis atau tidak tertulis. Peraturan sekolah akan dipatuhi siswa jika ada sangsi dan hukuman yang diberikan bagi yang melanggar aturan. Hal ini menjelaskan bahwasanya seseorang indiviu akan patuh apabila ada aturan-aturan yang mengikatnya. Dari penjelasan tersebut, berarti indikator disiplin kepatuhan tidak hanya dipengaruhi kelompok teman sebaya siswa saja, adanya tekanan yang kuat yang diberikan kelompok tidak membuat siswa memiliki kepatuhan, adanya sangsi dan hukuman yang diberikan oleh lembaga yakni sekolah ikut membuat siswa patuh terhadap aturan. Ini menyatakan bahwa faktor lingkungan dan sosial ikut mempengaruhi siswa dalam indikator kepatuhan.

Dari pembahasan di atas dapat disimpulkan bahwa disiplin siswa yang ditampilkan di SMA Negeri 5 Padang tahun ajaran 2011/2012 berada pada kategori sedang, dengan ini dapat diinterpetasikan bahwa disiplin yang ditampilkan siswa melalui indikator ketepatan waktu, kesadaran dan kepatuhan dipengaruhi oleh faktor psikologis, faktor sosial dan lingkungan. Ini menandakan kelompok teman sebaya merupakan bukan faktor yang paling dominan dalam mempengaruhi disiplin siswa

\section{Hubungan Konformitas Kelompok Teman Sebaya dengan Disiplin Siswa}

Dari hasil penelitian, pengujian hipotesis yang dilakukan terhadap siswa SMA Negeri 5 Padang dapat terlihat hubungan yang signifikan antara konformitas kelompok teman sebaya dengan disiplin dengan perolehan hasil perbandingan rhitung lebih besar dari $\mathrm{r}_{\text {tabel }}$ dengan nilai $r_{\text {hitung }} 0.570>r_{\text {tabel }} 0.207$ dengan signifikan sebesar 0.05 (5\%). Dari olahan data koefesien determinasi didapati $\mathrm{r}^{2}$ Square sebesar 0,3249 hal ini berarti $32,49 \%$ variabel disiplin dipengaruhi oleh variabel konformitas sedangkan sisanya $(100 \%-32,49 \%=67,51 \%)$. Dari data ini konformitas kelompok teman sebaya mempengaruhi disiplin siswa sebesar $32,49 \%$ dan $67,51 \%$ dipengaruhi oleh faktor lain seperti faktor psikologis, lingkungan dan perseorangan.

Hurlock (1994: 213), menjelaskan kebutuhan untuk diterima dalam kelompok teman sebaya menyebabkan remaja melakukan perubahan dalam sikap dan perilaku sesuai dengan perilaku anggota kelompok teman sebaya. Demikian pula bila anggota kelompok mencoba bolos, cabut, ribut, tidak buat PR, atau merokok, maka remaja cenderung mengikutinya tanpa 
memperdulikan akibatnya bagi diri mereka sendiri dan begitu sebaliknya. Hal tersebut tidak mengherankan, alasannya terkadang remaja yang dalam hal ini siswa begitu ingin diterima sehingga akan melakukan apapun sesuai penilaian dan persetujuan dari kelompok teman sebaya agar diterima dan diakui keberadaannya dalam kelompok, termasuk berprilaku disiplin. Kelompok teman sebaya yang memiliki konformitas yang positif terhadap disiplin maka akan menciptakan sikap disiplin yang tinggi, karena penolakan dalam kelompok teman sebaya sangat dihindari siswa.

Sesuai dengan teori referensi group yang terdiri dari (1) kelompok referensi normatif yaitu suatu kelompok yang menempatkan individu-individu dalam mengambil standar normatif dan standar moral. (2) Kelompok referensi komparatif yaitu kelompok yang memberikan kepada individu-individu suatu kerangka untuk menilai posisi sosialnya dalam hubungan dengan orang lain. (3) kelompok keanggotaan yaitu menunjukkan kepada suatu kelompok bahwa individu itu sebagai anggotanya.

Dalam hal ini siswa SMA Negeri 5 Padang yang berada pada kategori sedang diinterpretasikan siswa yang memiliki kelompok referensi normatif yaitu suatu kelompok yang menempatkan individuindividu dalam standar norma dan moral. Siswa memiliki kebebasan dalam melakukan tindakan karena masih berpandangan terhadap norma atau aturan yang dianggapnya benar. Apabila ada anggota kelompok melakukan pelanggaran disiplin, kecendrungan bagi individu (siswa) untuk mematuhi tindakan kelompok tersebut bukan suatu keharusan, karena dalam kelompok nomatif individu memiliki pandangan tersendiri terhadap norma yang dianggapnya benar.

Berdasarkan uji hipotesis dapat diketahui bahwa konformitas kelompok teman sebaya berpengaruh signifikan terhadap disiplin, bentuk pengaruh variabel konformitas kelompok teman sebaya ter- hadap disiplin adalah sedang. Hal ini diinterprestasikan korelasi antara konformitas kelompok teman sebaya dengan disiplin sedang artinya walaupun siswa memiliki ketertarikan terhadap kelompok teman sebayanya dengan menunjukan perilaku konformitas sedang akan mengakibatkan sikap disiplin yang sedang juga.

\section{Simpulan}

Berdasarkan hasil penelitian yang dilakukan di SMAN 5 Padang tahun ajaran 2011/2012 dapat diambil kesimpulan antara lain:

1. Pada variabel konformitas kelompok teman sebaya didapati secara umum siswa berada pada kategori sedang. Hal ini diinterpertasikan prilaku siswa sebagai hasil tekanan kelompok baik secara nyata ataupun tidak, melalui aspek kekompakkan, kesepakatan dan ketaatan dalam kategori sedang, siswa memiliki konformitas yang tidak berlebihan terhadap kelompok teman sebayanya karena, individu atau siswa memiliki kebebasan dalam menentukan tindakan dan prilakunya sesuai standar norma dan moral yang diyakini.

2. Pada variabel disiplin didapati secara umum siswa berada pada kategori sedang. Hal ini berarti tingkat ketepatan waktu, kepatuhan tehadap tata tertib dan kesadaran siswa terhadap disiplin sedang. Hal ini disebabkan karena disiplin siswa bukan hanya dipengaruhi oleh faktor teman sebaya, sesuai dengan hasil derajat koefesien determinasi yakni $32,49 \%$ variabel disiplin dipengaruhi oleh variabel konformitas sedangkan sisanya $(100 \%-32,49 \%=$ $67,51 \%)$ dipengaruhi faktor lainnya yakni faktor psikologis, faktor lingkungan dan faktor perseorangan.

3. Terdapat hubungan antara konformitas kelompok teman sebaya dengan disiplin sedang artinya walaupun siswa memiliki ketertarikan terhadap kelompok teman sebayanya dengan me- 
Irfan Setiawan, Ike Sylvia, HUBUNGAN ANTARA KONFORMITAS ...

nunjukkan perilaku konformitas sedang akan mengakibatkan sikap disiplin yang sedang juga.

Berdasarkan kesimpulan di atas dapat dikemukakan saran-saran sebagai berikut:

1. Diharapkan pada siswa dapat mengenali prilaku dan norma yang ada dalam kelompok teman sebaya.

2. Diharapkan pada siswa untuk memilih kelompok teman sebaya yang positif.

3. Diharapkan peran wali kelas dan guru BK untuk memantau kelompokkelompok siswa yang bermasalah untuk meminimalisir terjadinya pelanggaran disiplin.

4. Penelitian ini masih terbatas dalam masalah disiplin siswa yang dipengaruhi faktor teman sebaya. Sebaiknya bagi peneliti lanjutan agar mencoba untuk meneliti tentang faktor lain yang mempengaruhi disiplin.

\section{Daftar Rujukan}

Arikunto, Suharsimi. 2006. Prosedur Penelitian suatu Pendekatan Praktek. Jakarta: PT Rieneka Cipta

Azwar, Saifuddin. 1999. Penyusunan Skala Psikologi. Yogyakarta: Pustaka Pelajar

Crow and Crow. 1990. Pengantar Ilmu Pendidikan. Yogyakarta: Rakesarasin

Hurlock, B. Elizabeth. 1997. Psikologi Perkembangan Suatu Pendekatan Sepanjang Rentan Kehidupan. Jakarta: Erlangga

Monks, F.J, Knors, A.M.P, haditono, S.R. 2004. Psikologi Perkembangan. Yogyakarta: Gajah Mada University Presss

Prijodarminto, Soegeng. 1992. Peran Disiplin Kiat Menuju Sukses. Jakarta. PT. Pradnya Pramita
Ritzer, George dan Douglas J. Goodman. 2007. Teori Sosiologi Modern. Jakarta: Kencana

Santosa, Slamet. 2004. Dinamika Kelompok. Jakarta: Bumi Aksara

Santrock, J. 2002. Perkembangan Masa Hidup Jilid II. Edisi V. Jakarta: Erlangga

Sears, dkk.1991. Psikologi Sosial Jilid II. Alih Bahasa: Michael Adryanto. Jakarta: Erlangga

Soekanto, Soerjono. 2003. Sosiologi Suatu pengantar. Jakarta: Raja Grafindo Persada

Sugiyono. 2008. Metode Penelitian Pendekatan Kuantitatif, Kualitatif, dan RED. Bandung: Alfabeta

Sukardi. 2008. Metodelogi Penelitiann Pendidikan: Kompetensi dan Praktisinya. Jakarta: Bumi Aksara

Suwarno. S. W. 2003. Teori-teori Psikologi Sosial. Jakarta: PT Raja Grafindo Persada

Syahril, dkk. 2009. Profesi Kependidikan. Padang: UNP Press

Tu'u, Tulus. 2004. Peran Disiplin Pada Perilaku dan Prestasi Siswa. Jakarta: Grasindo

Vembrianto, 1993. Sosiologi Pendidikan. Jakarta: Gramedia

Dewi Sri Mawang Wulan. 2007. Hubungan Antara Peran Kelompok Teman Sebaya dan Interaksi Siswa dalam Keluarga dengan Kedisiplinan Belajar Siswa Kelas XI MAN 1 Sragen Tahun Ajaran 2006-2007. Fakultas Keguruan Ilmu Pendidikan Universitas Sebelas Maret. Skripsi.

Internet

http://psychemate.blogspot.com/2007/12/ konformitas-sosial.html/>[diakses tanggal 20 Oktober 2011]

http://pamogkasaba.wordpress.com/2010/ 03/19/konformitas-teman-sebaya/> [diakses tanggal 13 Oktober 2011] 